Www.jmscr.igmpublication.org

Impact Factor (SJIF): 6.379

Index Copernicus Value: 79.54

ISSN (e)-2347-176x ISSN (p) 2455-0450

crossrefDOI: https://dx.doi.org/10.18535/jmscr/v6i12.36

Journal Of Medical Science And Clinical Research

IGM Publication

An Official Publication of IGM Publication

\title{
Indications for uses of Homografts in Cardiac Patients at Sri Jayadeva Institute of Cardiac Sciences \& Research and Their Follow Up
}

\author{
Authors \\ Koneru Khatnani Lata', Gupta Animesh ${ }^{2}$, Bhat P.S. Seetharam ${ }^{3}$ \\ ${ }^{1}$ Postgraduate Resident, Department of CTVS, SJIC\&R, Bangalore - Karanataka \\ ${ }^{2}$ Postgraduate Resident, Department of Cardiology, SJIC\&R, Bangalore - Karanataka \\ ${ }^{3}$ Professor, Department of CTVS, SJIC\&R, Bangalore - Karanataka
}

\begin{abstract}
Aims and Objectives: To evaluate the indications for uses of homografts in cardiac patients at srijayadeva institute of cardiac sciences \& research and their follow up.

Methodology: Patients who received homografts in last two years (2012 to 2014) were included in this study. Homografts used in the study group, were processed, preserved and thawed according to protocols at our institute's tissue valve bank. Prospective data was collected for all cases from 1.8.2012 to 31.7.2014 in all surgical units at Sri jayadeva institute of cardiac sciences and research Bangalore and followed up postoperatively for evaluation by clinical and echographic assessment for 6 months of duration. Homograft heart valves were retrieved from non beating heart donors, usually from cadavers during postmartum. Surgeons collected the heart using aseptic precaution, with sterile instruments. A piece of tissue from aorta and pulmonary artery were collected for culture into sterile container. Heart with great vessels transported in sterile double bags over ice from mortuary to our institute's homograft valve bank. Heart was kept immersed in "Hank's balanced salt solution" (HBSS) with antibiotic at $4^{0} \mathrm{C}$, till dissection. Dissection of valve and conduit was done at earliest possible time. Homografts were kept moist during dissection by irrigation with HBSS. The coronary arteries were ligated and cut. Each valve was kept in $200 \mathrm{ml}$ of HBSS with antibiotics and incubated for 72 hours at $4^{0} \mathrm{C}$. The valves were transferred into fresh HBSS with antibiotic solution.After $72 \mathrm{hrs}$ of sterilisation homograft valves were prepared for freezing, under sterile conditions. Aortic and pulmonary valve were packed separately in cold HBSS $(90 \mathrm{ml}$ ) and $10 \mathrm{ml}$ of DMSO (dimethyl sulphoxide) solution. After the freezing cycle for $1^{1 /}{ }_{2}$ hours the valves were stored in vapour phase of liquid nitrogen between $-120^{\circ} \mathrm{C}$ to $-180^{\circ}$ C.The required valve was sent to operation theatre in cryo shipper maintaining the temperature below $-100^{\circ} \mathrm{C}$.The fast thawing procedure was used. Outer cover of cryobag was cut open and inner cover was handed over to the scrub nurse. The valve was rinsed for 5 to 10 minutes with sterile water at $40^{\circ} \mathrm{C}$. After that second and first bags were cut open and valve transferred into HBSS with DMSO 5\% Solution for 5 min rinse time, followed by two rinses in plain HBSS.

Results: Total of 23 patients had received homograft, from 1.8.2012 to 31.8 .2014 at our institute. 3 patients were died in perioperative period, hence excluded from the study.

Out of 20 live patients, 13 (65\%) were males and 7 (35\%) female. The disease distribution was $17(85 \%)$ cases out of 20 live patients were operated for a congenital disease (including bicuspid aortic valve). Rest 3(15\%) cases were operated for rheumatic and degenerative heart diseases. 3 out of the 23 patients died in our study. Two due to low cardiac output, in immediate perioperative period ( $<48 \mathrm{hrs})$ and one due to renal dysfunction followed by Multi organ dysfunction (MODS) in late postoperative period ( at 45 days). These patients were excluded from the statistical analysis pertaining to valve dysfunction. Pulmonary homografts were used in $13(65 \%)$ patients and aortic in the other 7 (35\%) patients with size ranging from $18-24 \mathrm{~mm}$ (mean-20.45 mm). Mean size of aortic homografts used is $19 \mathrm{~mm}$ while that of pulmonary homografts was $21.23 \mathrm{~mm}$. Pulmonary homografts were mainly used in
\end{abstract}


pulmonary circulation (10 cases). Only in 3 cases they were used in aortic position. Aortic homografts were used in both aortic (3 cases) and pulmonary position (4 cases).Most (12) of the homografts used (60\%) were cryopreserved for a period of less than 3 months. 25\% (5) were preserved for 3-6 months and 15\% (3)were older than that (>6 months). Of the 20 patients, 3 had homograft valve dysfunction in the post operative period- 2 were associated with homograft valvar regurgitation and 1 with homograft valvar stenosis (increased gradient). All 3 patients presenting with complications had homografts which were cryopreserved for less than 3 months with valve sizes 22-24 mm. Homograft pulmonary valve was used in all 3 cases, one in pulmonary and two in aortic position. Hence cryopreservation time, for implanted homografts, is not significantly associated with homograft dysfunction. Also, position of implanted pulmonary homograft (aortic / pulmonary) was statistically analysed in relation to homograft dysfunction using chi square test. Hence pulmonary homografts used in aortic position were related to significantly higher homograft dysfunction rate. In case of aortic homografts , 3 were used in aortic position and 4 in pulmonary position. However, none of these patients, developed homograft dysfunction/ complications. Probably, a larger series of patients or longer follow period is required to analyse the same.

Conclusion: Cryopreservation time was not significantly associated with homograft dysfunction. The use of pulmonary homografts in aortic position was associated with significantly higher complication and homograft dysfunction rate. The homograft valve is the best substitute and suited to Indian population. In cases of endocarditis of the native or mechanical prosthetic valve in the aortic position with coexisting abscesses of the ascending aorta, the implantation of a homograft is lifesaving. Logical use of homografts in adult and paediatric cardiac surgery when indicated with the proper surgical technique ensures a very good postoperative result and an excellent quality of life for the patient.

\section{Introduction}

The first implantation of a homograft in the descending aorta was performed by Murray, in $1956^{(1)}$. They were introduced into clinical practiceby the first orthotopic (aortic) homograft implantation by Ross in 1962 in England ${ }^{(2)}$. The sterilization of cadaveric homografts was initially performed with Gamma radiation or with Ethylene-oxide $^{(3,4)}$. Barratt-Boyes introduced the use of antibioticsin the sterilization process, in $1967^{(5)}$. Cryopreservation as the graft preservation method, which is currently in use, was introduced by the Australian M. O' Brien ${ }^{(6)}$. At that time, they were the only successful biological heart valve prosthesis beside the mechanical ones. To date there is no ideal valve substitute. Homografts offer many proven advantages, such as

Restoration of normal flow in the aorticroot, sinuses and coronary orifices, Superior hemodynamic properties over mechanical valves, low rate of thromboembolism, thus avoiding a lifetime of anticoagulation and Resistance to infection. Homografts evident disadvantages are Homograft implantation requires more complex technique of insertion, Limited availability, Limited durability which necessitates reoperation, inconvenience and cost. Homograft valves undergo early calcification with slow progression.
Thus, in 20 years, only $0 \%$ to $40 \%$ of homografts implanted are functional. Although the durability is higher compared with xenogeneic valves, it is still less than mechanical prostheses. These valves can be harvested from cadavers (patients who died due to non cardiac causes) within 24 hours of death, recipients of heart transplantation, from organ donors whose hearts are not accepted for heart transplantation for reasons other than valve problems.

\section{Methodology}

Patients who received homografts in last two years (2012 to 2014) were included in this study. Homografts used in the study group, were processed, preserved and thawed according to protocols at our institute's tissue valve bank. Prospective data was collected for all cases from 1.8.2012 to 31.7.2014 in all surgical units at Sri jayadeva institute of cardiac sciences and research Bangalore and followed up postoperatively for evaluation by clinical and echographic assessment for 6 months of duration. Inclusion criteria were patients, who received homograft from our (SJIC\&R) hospital valve bank \{Homograft was processed and preserved at our hospital (SJIC\& R) valve bank\}.Exclusion criteria were patients received homografts obtained from other banks, 
patients who received homografts, for vascular procedures, patients who died in perioperative period were excluded. The Criteria for collection of homograft were donor age should be less than 55 years, collection should be done within $24 \mathrm{hrs}$ of death of donor, donor should be serologically negative for HIV, HBV, HCV, or Syphilis. The Exclusion criteria were donor had septicemia, cancer or communicable disease, donor with history of heavy irradiation to chest area or collagen or immune complex diseases, donor, who had received an organ or tissue transplant, donor with Hemophillia.

Homograft heart valves were retrieved from non beating heart donors, usually from cadavers during postmartum. Surgeons collected the heart using aseptic precaution, with sterile instruments. A piece of tissue from aorta and pulmonary artery were collected for culture into sterile container. Heart with great vessels transported in sterile double bags over ice from mortuary to our institute's homograft valve bank. Heart was kept immersed in "Hank's balanced salt solution" (HBSS) with antibiotic at $4^{0} \mathrm{C}$, till dissection. Dissection of valve and conduit was done at earliest possible time. Donor's particular, cause and time of death, time of retrieval of heart, were documented. Blood from heart or femoral artery was collected for serology tests for HIV, HBV, $\mathrm{HCV}$, Syphilis and blood grouping. Heart was washed sterile saline to remove all traces of blood clots. This was transported into laminar flow hood. Aortic and pulmonary valves and conduit were dissected. Homografts were kept moist during dissection by irrigation with HBSS. The coronary arteries were ligated and cut. The aortic root was trimmed at a level $1 \mathrm{~cm}$ below the lowest part of aortic leaflets. Excessive tissue was removed to reduce external diameter and mass of root. The valves were examined for congenital variation, calcification, athroma, and fatty streaks. The valves or conduits were discarded for following presence of fenestration, congenital defects, Serology positivity ,Fungal growth in any culture, Calcific deposits and presence of atheroma. To size the valve, obturators were used and diameter was noted. Length was measured with sterile scale. Each valve was kept in $200 \mathrm{ml}$ of HBSS with antibiotics and incubated for 72 hours at $4^{0} \mathrm{C}$. The valves were transferred into fresh HBSS with antibiotic solution at the end of $24 \& 48$ hours. The components of the antibiotic solution was Amikacin-100mcg/ml, Amphotericin B- $25 \mathrm{mcg} / \mathrm{ml}$, Vancomycin - $50 \mathrm{mcg} / \mathrm{ml}$, Cefotaxime- $250 \mathrm{mcg} / \mathrm{mland}$ Gentamycin$120 \mathrm{mcg} / \mathrm{ml}$. The composition of the antibiotic solution is chosen such that all pathogens are eliminated, while toxic influence on the cells of the homograft wall is being avoided. Tissues was taken at mortuary, from saline wash and after 24, $48 \& 72$ hours of antibiotic sterilisation. Tissues were cultured for isolation of bacteria as well as fungi. After $72 \mathrm{hrs}$ of sterilisation homograft valves were prepared for freezing, under sterile conditions. Aortic and pulmonary valve were packed separately in cold HBSS (90 ml) and 10 $\mathrm{ml}$ of DMSO (dimethyl sulphoxide) solution. The top of plastic bag was sealed, without any air bubble. This sealed bag was placed in $2^{\text {nd }}$ aluminium lined cryobag and sealed again. Once again it was placed in the third pouch with identification card and sealed. The triple packed pouch was placed into a plastic box which had been numbered earlier and kept in fridge.

DMSO is toxic to cells above $10{ }^{0} \mathrm{C}$ hence the packed valve were kept in fridge or on ice till they were cryo preserved. Following packaging, Homograft valves were placed in the controlled rate freezer, which would freeze the valve at approximately $-1{ }^{0} \mathrm{C} / \mathrm{min}$. After the freezing cycle for $1{ }^{1 /}$, hours the valves were stored in vapour phase of liquid nitrogen between $-120{ }^{0} \mathrm{C}$ to $180^{\circ} \mathrm{C}$.

The required valve was sent to operation theatre in cryo shipper maintaining the temperature below $100^{\circ} \mathrm{C}$.The fast thawing procedure was used. Outer cover of cryobag was cut open and inner cover was handed over to the scrub nurse. The valve was rinsed for 5 to 10 minutes with sterile water at $40^{\circ} \mathrm{C}$. After that second and first bags 
were cut open and valve transferred into HBSS with DMSO 5\% Solution for $5 \mathrm{~min}$ rinse time, followed by two rinses in plain HBSS.

\section{Results}

Total of 23 patients had received homograft, from 1.8.2012to 31.8.2014 at our institute. 3 patients were died in perioperative period, hence excluded from the study.

Out of 20 live patients, 13 (65\%) were males and 7 (35\%) female.

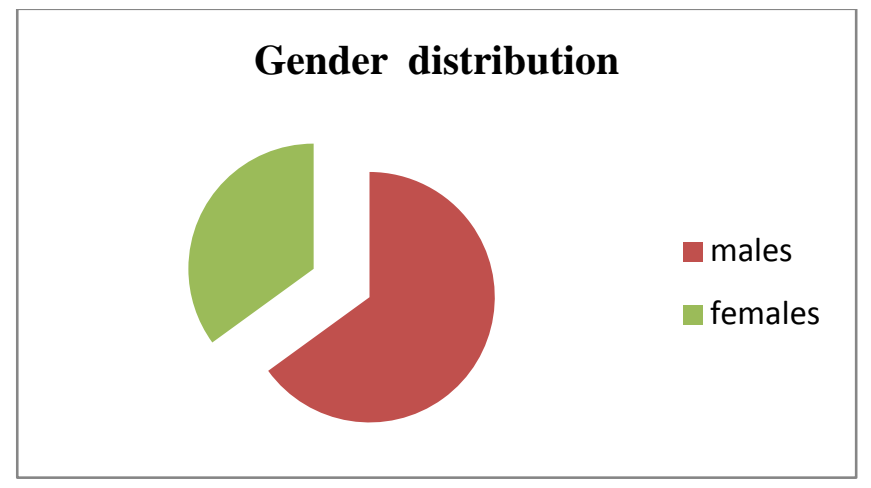

Age ranged from 3-76 years with a mean of 18.3 years.

Disease distribution $-17(85 \%)$ cases out of 20 live patients were operated for a congenital disease (including bicuspid aortic valve). Rest $3(15 \%)$ cases were operated for rheumatic and degenerative heart diseases.

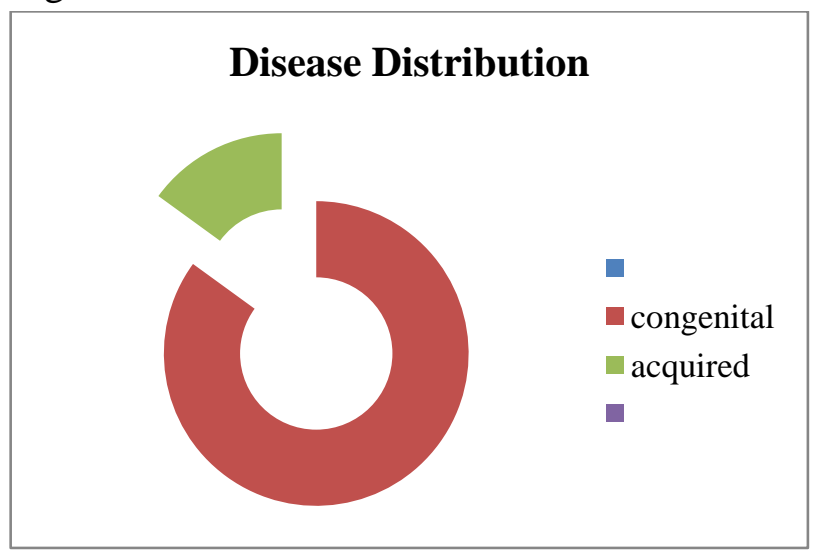

Following were the indications and procedure performed in our study group.

\begin{tabular}{|c|c|c|c|}
\hline S.no. & DIAGNOSIS & Age/ Sex & PROCEDURE \\
\hline 1 & $\begin{array}{c}\text { CHD, SS, TOF, PULMONARY } \\
\text { ATRESIA }\end{array}$ & 16/M & ICR + RV TO PA CONDUIT \\
\hline 2 & CHD, SS , TOF, SEV PS & $4 / \mathrm{M}$ & ICR + RV TO PA CONDUIT \\
\hline 3 & RHD, SEV MR, SEV AR & $11 / \mathrm{M}$ & MV REPAIR + AVR (HOMOGRAFT) \\
\hline 4 & $\begin{array}{l}\text { CHD, SS, TOF, ABSENT } \\
\text { PULMONARY VALVE }\end{array}$ & 24/M & ICR + PV REPLACEMENT (HOMOGRAFT \\
\hline 5 & CHD, SS, SEV AS (BICUSPID) & 6/M & ROSS PROCEDURE \\
\hline 6 & BICUSPID AV, SEV AS, MOD AR & $18 / \mathrm{M}$ & AVR (HOMOGRAFT) \\
\hline 7 & CHD, SS, TGA, VSD & 3/M & RASTELLI'S PROCEDURE \\
\hline 8 & CHD,SS, PM VSD, SEV PR & $22 / \mathrm{F}$ & ICR, PV REPLACEMENT (HOMOGRAFT) \\
\hline 9 & CHD , SS, SEV PS WITH SEV PR & 24/M & PULM VALVE REPLACEMENT (HOMOGRAFT) \\
\hline 10 & $\begin{array}{l}\text { CHD, SS, TOF, ABSENT PULM } \\
\text { VALVE }\end{array}$ & 20/M & ICR+ PULM HOMOGRAFT IMPLANTATION \\
\hline 11 & CHD, SS, PULM ATRESIA, VSD & $6 / \mathrm{F}$ & ICR + RV TO PA CONDUIT \\
\hline 12 & S/P VSD RSOV CLOSURE, SEV PR & $27 / F$ & PULM VALVE REPLACEMENT (HOMOGRAFT) \\
\hline 13 & CHD, SS , SEV PS & $18 / \mathrm{F}$ & PULM VALVE REPLACEMENT (HOMOGRAFT) \\
\hline 14 & CHD, SS, SEV AR & $8 / \mathrm{M}$ & ROSS PROCEDURE \\
\hline 15 & BAV, SEV AS, IE & 28/M & AVR (HOMOGRAFT) \\
\hline 16 & CHD, SS,CCTGA, VSD,PS & $32 / \mathrm{M}$ & RASTELLI'S PROCEDURE \\
\hline 17 & $\begin{array}{c}\text { CHD,SS TOF WITH ABSENT PULM } \\
\text { VALVE }\end{array}$ & $31 / \mathrm{M}$ & $\begin{array}{c}\text { ICR + PULMONARY HOMOGRAFT } \\
\text { IMPLANTATION }\end{array}$ \\
\hline 18 & SEV CALCIFIC AS & $76 / \mathrm{F}$ & AVR (HOMOGRAFT) \\
\hline 19 & $\begin{array}{c}\text { CHD,SS, TOF, WITH PULMONARY } \\
\text { ATRESIA }\end{array}$ & $10 / \mathrm{F}$ & ICR + RV TO PA CONDUIT \\
\hline 20 & RHD, SEV MR, SEV AR & $17 / \mathrm{F}$ & MVREPAIR +AVR (HOMOGRAFT) \\
\hline $21^{*}$ & CHD, SS, CCTGA, VSD, PS & $13 / \mathrm{M}$ & SENNINGS + RASTELLI'S PROCEDURE \\
\hline $22^{*}$ & CHD,SS,CCTGA,VSD PS & $8 / \mathrm{M}$ & RASTELLI'S PROCEDURE \\
\hline $23^{*}$ & CHD, SS, DTGA, VSD, PS & $3.5 / \mathrm{M}$ & RASTELLI'S PROCEDURE \\
\hline
\end{tabular}

*Last 3 out of the 23 patients died in our study.

Two due to low cardiac output, in immediate perioperative period $(<48 \mathrm{hrs})$ and one due to renal dysfunction followed by Multi organ 
dysfunction (MODS) in late postoperative period (at 45 days). These patients were excluded from the statistical analysis pertaining to valve dysfunction. Pulmonary homografts were used in $13(65 \%)$ patients and aortic in the other $7(35 \%)$ patients with size ranging from 18- $24 \mathrm{~mm}$ (mean $-20.45 \mathrm{~mm}$ ). Mean size of aortic homografts used is $19 \mathrm{~mm}$ while that of pulmonary homografts was $21.23 \mathrm{~mm}$. Pulmonary homografts were mainly used in pulmonary circulation (10 cases). Only in 3 cases they were used in aortic position. Aortic homografts were used in both aortic ( 3 cases) and pulmonary position (4 cases).

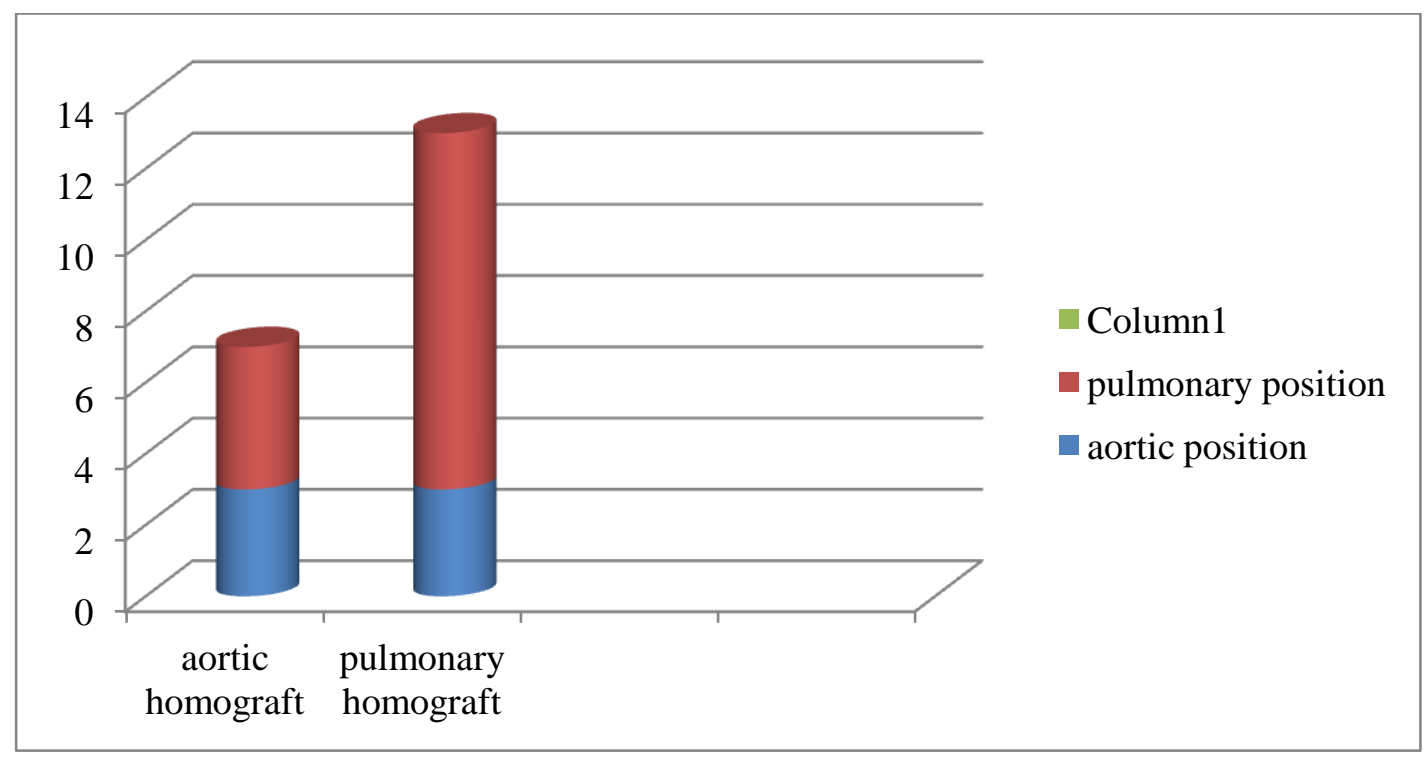

\section{Cryopreservation time}

Most (12) of the homografts used (60\%) were cryopreserved for a period of less than 3 months.
$25 \%$ (5) were preserved for 3-6 months and $15 \%$ (3)were older than that ( $>6$ months)

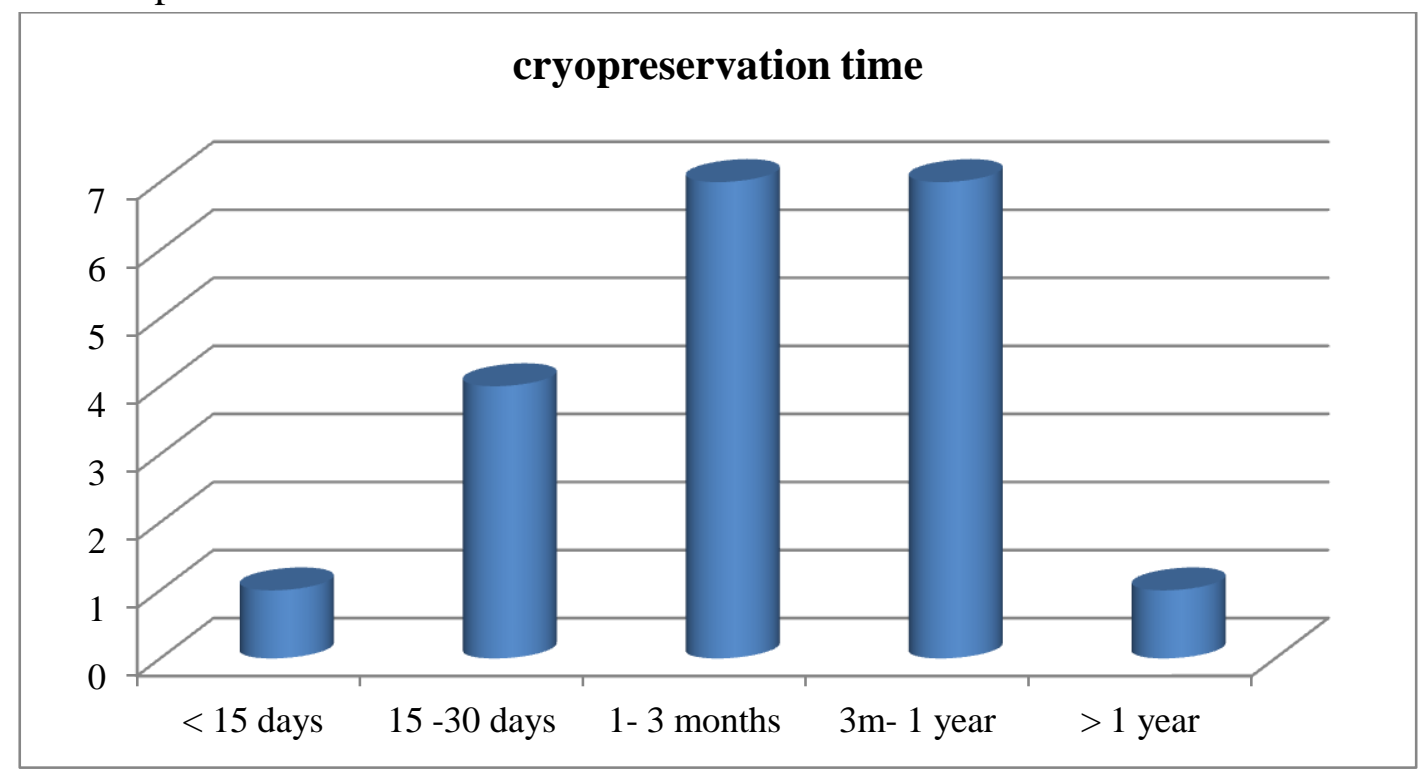

\section{Post op complication}

Of the 20 patients, 3 had homograft valve dysfunction in the post operative period- 2 were associated with homograft valvar regurgitation and 1 with homograft valvarstenosis (increased gradient). All 3 patients presenting with complications had homografts which were cryo preserved for less than 3 months with valve sizes 22-24 mm. Homograft pulmonary valve was used in all 3 cases, one in pulmonary and two in aortic 
position. Statistical analysis for relation between cryopreservation time and homograft valve dysfunction using chi-square test was done.

\begin{tabular}{|l|c|c|c|}
\hline $\begin{array}{l}\text { Cryopreservation } \\
\text { time }\end{array}$ & $\begin{array}{c}\text { No } \\
\text { complications }\end{array}$ & Complications & Total \\
\hline$<3$ months & 9 & 3 & 12 \\
\hline$>3$ months & 8 & 0 & 8 \\
\hline Total & 17 & 3 & 20 \\
\hline
\end{tabular}

$\mathrm{p}=0.2421(>0.05)$

Hence cryopreservation time, for implanted homografts, is not significantly associated with homograft dysfunction. Also, position of implanted pulmonary homograft (aortic / pulmonary) was statistically analysed in relation to homograft dysfunction using chi square test.

\begin{tabular}{|l|c|c|c|}
\hline $\begin{array}{l}\text { Homograft } \\
\text { position }\end{array}$ & $\begin{array}{c}\text { No } \\
\text { dysfunction }\end{array}$ & Dysfunction + & Total \\
\hline Aortic & 1 & 2 & 3 \\
\hline Pulmonary & 9 & 1 & 10 \\
\hline Total & 10 & 3 & 13 \\
\hline
\end{tabular}

$\mathrm{p}=0.04(<0.05)$--- statistically significant

Hence pulmonary homografts used in aortic position were related to significantly higher homograft dysfunction rate. In case of aortic homografts, 3 were used in aortic position and 4 in pulmonary position. However, none of these patients, developed homograft dysfunction/ complications. Probably, a larger series of patients or longer follow period is required to analyse the same.

\section{Discussion}

Aortic, pulmonary, very rarely mitral valves and pericardium are currently used for valve replacement and other cardiac surgical procedure. Aortic valves are used for aortic valve replacement (AVR) in cases of aortic valve infective endocarditis, in younger age group. Pulmonary valve are used for correction of congenital defects, RVOT reconstruction, Ross procedure. Mitral valve (MV) are used as entire valve or part of MV repair. Pericardium has also been used for various congenital defects recently. Homograft valve implantation indicated in following

\section{Endocarditis}

Adult patients with persistent native valve or prosthetic valve endocarditis involving the aortic valve may require aortic valve replacement. Homograft aortic valve is replacement of choice, due to decrease incidence of recurrent bacterial endocarditis ${ }^{(7)}$.

The properties of homograft are:-

1. homografts possess anti-infective properties;

2. In homografts living cells has been demonstrated at the time of implantation, these living grafts are resistant for bacterial infection.

3. when using the mini-root technique, they allow the replacement of annular tissue and parts of the anterior mitral leaflet. It allows the most radical excision of all infective tissues.

\section{Congenital heart diseases}

A number of operations used for correction of complex congenital heart disease requires valved and non valved conduits.

In Norwood procedure or reconstruction of the ascending aorta and aortic arch for hypoplastic left heart syndrome, reconstruction of the right ventricular outflow tract in Tetralogy of Fallot with pulmonary atresia (right ventricle to pulmonary artery conduits) \& in Rastelli's operation, homografts are required.

\section{Mitral valve replacement}

Homografts for mitral valve replacement, rarely used, mostly with endocarditis. Implantation techniqueis very demanding and evidence of reduced durability is there; hence it suse is still experimental $^{(8)}$.

\section{Ross procedures}

Ross procedure uses the patient's pulmonary valve as a substitute for the aortic valve. The homograft is then implanted in the pulmonary position. The hemodynamic situation thereafter is excellent with regards to the left ventricle and the degeneration rate of the new aortic valve is very low. Degeneration normally occurs at the site of the implanted homograft in the pulmonary position.

The Ross procedure seems to be most effective in young patients, avoids lifetime anticoagulation with excellent hemodynamics.

\section{Others}

Patients with a small aortic annulus aortic valve replacement without annular enlargement can be 
done using an aortic homograft or a Ross Operation as these valves do not downsize the aortic annulus.

Patients with a medical contraindication to anticoagulation or want to avoid anticoagulation (female patient of child bearing age, etc.) may be candidates for a homograft valve rather than a mechanical prosthesis. Replacement with bioprosthetic valve also an alternative. Patients with periprosthetic insufficiency and evidence of dehiscence of the prosthetic aortic annulus and the native aortic annulus can be managed with aortic homograft root replacement of the prosthetic valve. Patients with ascending aortic aneurysm and associated aortic valve disease may require homobent all operation (replacement of ascending aorta and aortic valve with homograft root). The advantages of homograft use are: rare chances of thromboembolic events, hence no need for anticoagulation, absence of haemolysis, lack of ring/cuff of graft support (minimising the transvalvular gradient compared to the stented prosthetic valves) ,optimum haemodynamic performance (similar to that of stentless valves), higher resistance to endocarditis compared to all the other valves, etc. Use of homografts as a complete aortic root replacement in cases of complex aortic valve endocarditis, allows the resection or isolation from the circulatory system of all the infected tissues with radical elimination of the infection. The homografts can be used for the replacement of the aortic valve in three ways:

a) Replacement of the valve with graft implantation under the coronary ostia (subcoronary implantation),

b) "mini" replacement of the aortic root with intraluminal implantation of the graft (mini-root) and

c) Complete aortic root replacement with reimplantation of the coronary arteries ${ }^{(10)}$. The latest results from the use of homografts in the aortic position are very good in Doty et $\mathrm{al}^{(11)}$ report 10-year freedom from valve-related mortality - 93\%, from thromboembolic events $100 \%$, from valve endocarditis $-98 \%$ and from re- operation - 92\%.Vogt et al report a 97\% 5-year survival, with freedom from reoperation and endocarditis $69 \%$ and $85 \%$ respectively $^{(12)}$. In our study total seven aortic homografts were used. There were no valve related mortality, no thromboembolic events and no valve endocarditis in 6 months post surgery in our study group. A larger no of patients and longer follow-up period is required to analyse long term results. Pulmonary homografts are used in paediatric cardiac surgery for correction of congenital anomalies, in Ross procedure for the pulmonary valve replacement and in the replacement of the aortic valve ${ }^{(13)}$ In the first two, results are very good, while in the aortic position are inferior to aortic homografts ${ }^{(14)}$, because their use constitutes an independent prognostic factor of valvular insufficiency ${ }^{(15)}$. The pulmonary valve leaflet has similar radial and longitudinal stress characteristics to the aortic valve leaflet. The pulmonary artery or root has very dissimilar characteristics to those of the aorta or aortic root. The forces that develop in the aortic root can dilate a pulmonary homograft roughly about $30 \%$ more than an aortic ${ }^{(16)}$, thus causing insufficiency of the valve in up to $1 / 3$ of the patients ${ }^{(17)}$.There are series of patients where severe stenosis of the graft (> $20 \mathrm{mmHg}$ transvalvular gradient) was found in up to $1 / 3$ of patients after 3 years ${ }^{(18)}$. Various factors, such as the age of the donor and a short period of graft cryopreservation that could lead to increased cellular viability and activation of the immune system ${ }^{(18)}$.

In our study group 13 pulmonary homografts were used, out of which 3, had valve degeneration and dysfunction at the 6 months postoperatively. On statistical analysis, valve dysfunction in 2 patients is attributed to pulmonary homograft implantation at aortic position.

$\mathrm{p}$ value is $.04(<.05)$, hence significant. Thus early, limited, short-term experience with pulmonary homograft replacement of the aortic valve and root was not satisfactory in our study. Different techniques of sterilization, preservation 
and storage are described in literature. Presently mainly two techniques are applied

\section{Fresh-Wet Storage}

It is done at $4{ }^{\circ} \mathrm{C}$ after antibiotic sterilization. It results in more viable donor cells at implantation and therefore might increase the immunologic response of the recipient.

\section{Cryopreservation}

Cryopreservation is a process where cells or whole tissues are preserved by cooling to low subzero temperatures, such as $77 \mathrm{~K}$ or $-196{ }^{\circ} \mathrm{C}$ (the boiling point of liquid nitrogen). At these low temperatures, any biological activity, including the biochemical reactions that would lead to cell death, is effectively stopped. However, when vitrification solutions are not used, the cells being preserved are often damaged due to freezing during the approach to low temperatures or warming to room temperature.

It is done in the vapour phase of liquid nitrogen. Cryopreservation has the advantage of the possibility of a long storage period.

Phenomena which can cause damage to cells during cryopreservation are solution effects, extracellular ice formation, dehydration and intracellular ice formation.

\section{(I) Solution effects}

Solution effects caused by concentration of solutes in non-frozen solution during freezing as solutes are excluded from the crystal structure of the ice. High salt concentrations can be very damaging.

\section{(II) Extracellular ice formation}

When tissues are cooled slowly, water migrates out of cells and ice forms in the extracellular space. Excessive extracellular ice can cause mechanical damage due to crushing

\section{(III) Dehydration}

The migration of water causing extracellular ice formation can also cause cellular dehydration. The associated stresses on the cell can cause damage directly.

\section{(IV) Intracellular ice formation}

While some organisms and tissues can tolerate some extracellular ice, any appreciable intracellular ice is almost always fatal to cells.

\section{Prevention}

Vitrification provides the benefits of cryopreservation without the damage due to ice crystal formation. In clinical cryropreservation, vitrification requires the addition of cryoprotectants prior to cooling. The cryoprotectants act like antifreeze: they lower the freezing temperature. They also increase the viscosity. Instead of crystallizing, it vitrifies. Vitrification of water is promoted by rapid cooling, and can be achieved without cryoprotectants by an extremely rapid drop in temperature (megakelvins per second). Two conditions usually required to allow vitrification are an increase in the viscosity and a depression of the freezing temperature. Rapid cooling also promotes vitrification. In artificial cryopreservation, the solute must penetrate the cell membrane in order to achieve increased viscosity and depressed freezing temperature inside the cell. Solutes, such as dimethyl sulfoxide, a common cryoprotectant, function similarly, but they are toxic in high concentration. Cryopreservation is limiting the damage produced by the cryoprotectant itself. During the rewarming process, a homogenous defrosting of the complete graft should be achieved to prevent any interstitial ice formation as crystallization of interstitial water can be the starting point of early degeneration. In both processes complete sterile processing and storage should be assured and must be controlled by repeated microbiological testing of the fluids used for storage, to prevent the contamination of the homograft.

\section{Protocols of homografts processing technique at our institute-}

Homograft retrieval is performed within 48 hours from death. After harvesting, the grafts are placed in an antiseptic solution containing a combination of antibiotics, where they remain at $4^{0} \mathrm{C}$ for 3 days. During this period the tissues are tested for contamination (aerobic, anaerobic, fungi, etc) and examined for HIV, HbsAg, Anti-HCV, syphilis. After adetailed macroscopic examination, they are kept frozen at $-180^{\circ} \mathrm{C}$ in liquid nitrogen 
(cryopreservation) facilitating their preservation for up to 5 years. Unsuitability of homografts results when the donor either has a history of AIDS, hepatitis $\mathrm{B}$ or $\mathrm{C}$, syphilis or other contagious disease (of various pathology).

The histocompatibility (HLA) control- homograft crosshatching - to avoid graft degeneration (due to the activation of the recipient's immune system leading to antibody formation), although still performed in certain centres, is not done at our centre, as the valvular endothelium lacks expression of carbohydrate antigens ${ }^{(20)}$.

\section{Conclusion}

Cryopreservation time was not significantly associated with homograft dysfunction. The use of pulmonary homografts in aortic position was associated with significantly higher complication and homograft dysfunction rate. The homograft valve is the best substitute and suited to Indian population. The cost is affordable and the quality of life is good. In cases of endocarditis of the native or mechanical prosthetic valve in the aortic position with coexisting abscesses of the ascending aorta, the implantation of a homograft is lifesaving. Logical use of homografts in adult and paediatric cardiac surgery when indicated with the proper surgical technique ensures a very good postoperative result and an excellent quality of life for the patient.

\section{References}

1. Murray G. Homologous aortic valve segment transplants as surgical treatment for non-aortic and mitral insufficiency. Angiology. 1956;7:446-471

2. Homograft replacement of the aortic valve. ROSSDN Lancet. 1962 Sep 8; 2(7254):487

3. Barratt-Boyes BG: Homograft aortic valve replacement in aortic incompetence and stenosis. Thorax 1964; 19: 131-135.

4. Malm JR Bowman FO, Harris PD, Kovalik ATW: An evaluation of aortic homografts sterilized by electron-beam energy. J Thorac Cardiovasc Surg 1967; 54: 471-475.

5. Barratt-Boyes BG, Roche AHG, Whitlock RML: Six year review of the results of freehand aortic valve replacement using an antibiotic sterilized homograft valve. Circulation 1977; 55: 353-361.

6. O'Brien MF, Stafford EG, Gardner MAH, et al: A comparison of aortic valve replacement with viable cryopreserved and fresh allograft valves, with a note on chromosomal studies. J Thorac Cardiovasc Surg 1987; 94: 812-823

7. Homograft reconstruction of the aortic root for endocarditis with periannular abscess: a 17-year study. Yankah AC, Pasic $M$, Klose H, Siniawski H, Weng Y, Hetzer $R$ Eur J Cardiothorac Surg. 2005 Jul; 28(1):69-75.

8. Gulbins H, Anderson I, Kilian E, et al. Five years experience with mitral valve homografts. Thorac Cardiovasc Surg 2002; 50: 223-229

9. Carr-White GS, Kilner PJ, Hon JK, et al. Incidence, location, pathology and significance of pulmonary homograft stenosis after the Ross operation. Circulation 2001; 104:I16-20.

10. Oury JH, Angel WW, Eddy AC, Cleveland JC: Pulmonary autograft - past, present and future. J Heart Valve Dis 1993;2: 365375.

11. Doty JR, Salazar JD, Liddicoat JR, Flores JH, Doty DB: Aortic valve replacement with cryopreserved aortic allograft: tenyear experience. J ThoracCardiovascSurg 1998; 115: 371-379.

12. Vogt PR, von Segesser LK, Jenni R, Niederhauser U, Genoni M, Kunzli A, et al: Emergency surgery for acute infective aortic valve endocarditis: performance of cryopreserved homografts and mode of failure. Eur J Cardiothorac Surg 1997; 11: 53-61. 
13. Dacey LJ: Pulmonary homografts: current status. Curr Opin Cardiol 2000; 15: 86-90.

14. Koolbergen DR, Hazekamp MG, de Heer E, et al: Structural degeneration of pulmonary homografts used as aortic valve substitute underlines early graft failure. Eur J CardiothoracSurg 2002; 22: 802807.

15. Choudhary SK, Saxena A, Dubey B, Kumar AS: Pulmonary homograft: should it be used in the aortic position? J ThoracCardiovascSurg 2000; 120: 148155

16. Vesely I, Casarotto DC, Gerosa G: Mechanics of cryopreserved aortic and pulmonary homograft. J Heart Valve Dis 2000; 9: 27-37.

17. Naegele H, Bohlmann M, Doring V, Kalmar P, Rodiger W: Results of aortic valve replacement with pulmonary and aortic homografts. J Heart Valve Dis 2000; 9: $215-220$

18. Raanani E, Yau TM, David TE, Dellgren G, Sonnenberg BD, Omran A: Risk factors for late pulmonary homograft stenosis after the Ross procedure. Ann ThoracSurg 2000; 70:1953-1957.

19. Ross DN: Reflections on the pulmonary autograft. J Heart Valve Dis 1993; 2: 363364.

20. Selthilnathan V, Treasure T, Grunkemeier G, Starr A. Heart valves: which is the best choice? CardiovascSurg 1999; 7: 393-397.

21. Simon P, Kasimir MT, Seebacher G, et al. Early failure of tissue engineered porcine heart valve Synergraft in pediatric patients. Eur J Cardiothorac Surg. 2003; 23: 10021006.

22. Cebotari S, Mertsching H, Kallenbach K, et al. Construction of autologous human heart valved based on an acellular allograft matrix. Circulation 2002; 106; I63-I68.
23. Zehr KJ, Yagubyan M, Connolly HM, et al. Aortic root replacement with a novel decellularized cryopreserved aortic homograft: Postoperative immunoreactivity and early results. $\mathbf{J}$ Thorac Cardiovasc Surg. 2005; 130: 1010-1015.

24. Hopkins RA, Jones AL, Wolfinbarger L, et al. Decellularization reduces calcification while improving both durability and 1-year functional results of pulmonary homograft valves in juvenile sheep. $J$ Thorac Cardiovasc Surg. 2009; 137: 907-913.

25. da Costa FD, Costa AC, Prestes R, et al. The early and midterm function of decellularized aortic valve allografts.Ann Thorac Surg. 2010; 90: 1854-60.

26. Brown JW, Ruzmetov M, Eltayeb O, et al. Performance of Synergraft decellularized pulmonary homograft in patients undergoing a Ross procedure. Ann Thorac Surgery 2011; 91: 416-423.

27. Elkins RC, Goldstein S, Hewitt CW, et al. Recellularization of heart valve grafts by a process of adaptive remodeling. Semin Thorac Cardiovasc Surg. 2001; 13: 87-92 